Dragana Z. Marković Nikolić1, Goran Petković ${ }^{1}$, Nebojša Ristić1, Tanja Nikolić1, Aleksandar Zdravković ${ }^{1}$, Danijela Stojadinović ${ }^{1}$, Stanko Žerajić ${ }^{2}$, Goran S. Nikolić ${ }^{2 *}$

${ }^{1}$ High Technologically Artistic Professional School, Leskovac, Serbia

${ }^{2}$ University of Niš, Faculty of Technology, Leskovac, Serbia
Scientific paper ISSN 0351-9465, E-ISSN 2466-2585 UDC: $631.147: 662.767 .2$ doi: $10.5937 /$ zasmat1902197M

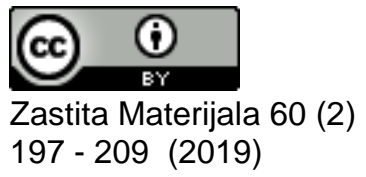

\title{
The green modification of lagenaria vulgaris agro-waste: spectroscopic and morphological analysis
}

\begin{abstract}
Recently, research on the exploitation and conversion of agricultural residues into value added products for the production of various important biomolecules of economic importance has been actively implemented. Therefore, the modification of bottle gourd (Lagenaria vulgaris) shell (BGS), as a potentially valuable agro-waste, by a green carbonate treatment has been analyzed in this study. The biochemical composition, structural and morphological changes of BGS biomass during the treatment were monitored using physicochemical, spectroscopic (FTIR) and microscopic (SEM) methods. The partial delignification and removal of extractive substances from the lignocellulosic biomass, such as oligosaccharides of depolymerized hemicellulose, organic acids, lignin fragments, and possibly trapped minerals have been disclosed. In this way, increased porosity of the cellulose enriched BGS biomass, as well as the activation of cellulosic microfibrils to alkaline-cellulose has been achieved. It was found that these changes are an important prerequisite for making a precursor of biosorbent which can be applied in wastewater treatment technology.
\end{abstract}

Keywords: bottle gourd, lignocellulosic biomass, modification, green solution, FTIR, SEM.

\section{INTRODUCTION}

Lignocellulosic biomass as a composite material is widely available agro-waste worldwide. The high availability of lignocellulosic agro-waste has stimulated an increasing interest in the replacement of synthetic materials, especially as biosorbent in the wastewater treatment technology, due to the growing ecological constraints and regulatory requirements such as recyclability, sustainability and renewability [1]. Besides their low prices, favorable physicochemical and mechanical properties and ecological characteristics of the natural materials (light weight, low density, easier handling and processing, high specific strength, non-abrasiveness, and nontoxicity) have made them potential candidates for the development of various derivatives or composites with significant characteristics.

The potential application of lignocellulosic biomass depends on the origin and character of its

\footnotetext{
${ }^{*}$ Corresponding author: Goran S. Nikolic

E-mail: goranchem_yu@yahoo.com

Paper received: 27.03.2019.

Paper accepted: 30.04.2019.

Paper is available on the website:

www.idk.org.rs/journal
}

surface, from which adsorption capacity or a chemical reaction is most often required. Modification of the lignocellulosic surface can very often make the biomass more convenient for subsequent processes [2]. A wide range of different approaches can be applied to modify the lignocellulosic surface: alkaline processing (for partial delignification), acid treatment (for complete depolymerization of polysaccharides to monosaccharides), and treatment with various organic solvents, oxidative delignification (hydrogen peroxide, ozonolysis), biological treatment (by using microbes) and microwave radiation [3].

However, although it is possible to change the surface characteristics of the given lignocellulosic material in order to be suitable for a selected application, all existing strategies would not be economical. Also, even though the lignocellulosic biomass itself can be viewed in general as environmentally friendly for production, there is a risk that the product thus obtained would no longer be justified from the aspect of green chemistry after intensive alteration, especially if there was a high energy intake, nonrecoverable solvents or contaminants of various types [4]. Therefore, in an effort to be economical and responsible, one attempts to meet the performance requirements of 
various applications at minimal cost and with minimal harmful impact on the environment.

Proper degradation of agricultural residues can allow adequate exploitation of the lignocellulosic materials. The destruction of lignocellulosic biomass is an important part of the process requirements for biomass processing. However, the partial distortion of a mechanically strong lignocellulosic structure may be a problem since the developed processing methods are not selective and effective for this purpose. Of the studied biomass treatment technologies, the most significant are those related to the green liquid application [2]. The green treatment process was established for the improving on the structural and morphological properties of the lignocellulosic biomass. Therefore, optimization of this process for different biomasses is very important.

The bottle gourd (genus Lagenaria), one of the first cultivated plants in the world, is a genus of gourd-bearing vines in the squash family (Cucurbitaceae). The best-known species Lagenaria vulgaris Ser. is a cultivated plant grown for its fruit [5]. The fruit can be harvested young and used as a vegetable. The fruit pulp has been known for its healing properties, and has been utilized for treatment of various ailments since ancient times [6]. The bottle gourd is collected mature, then dried, and exploited in making utensils, musical instruments, pipes, bottles, or water containers (Fig. 1). As the main structural components of the plant cell wall, the fresh $L$. vulgaris fruit shell contains crude protein, polysaccharides and lignin [7]. The dried gourd fruit is a hard material with lignocellulosic structure. Depending on the origin and storage conditions, the dried $L$. vulgaris shell mainly contains polysaccharides (cellulose 35-40\%, hemicellulose $15-20 \%$ ) and lignin (35-40\%) [8]. The chemical and physical properties of the shell depend on the content and structure of these polymers in biomass. One of the ways to improve the properties of this material is chemical modification with the appropriate reagent [9].
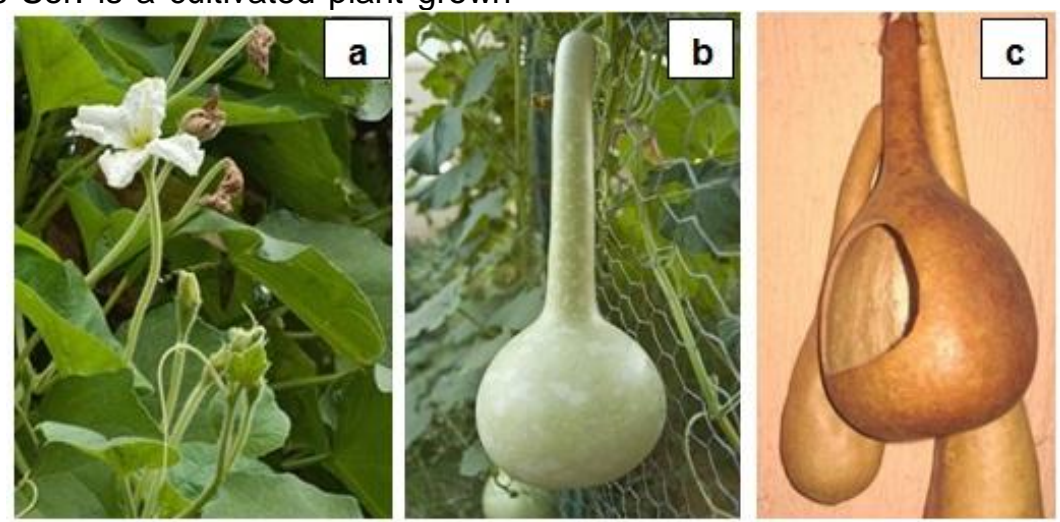

Figure 1. The flower Lagenaria vulgaris (a), fresh fruit (b) and dried fruit (c) of bottle gourd

Slika 1. Cvet Lagenaria vulgaris (a), sveži plod (b) i suvi plod (c) tikve sudovnjače

This research considers one of the ways to change the surface of lignocellulosic biomass not only in terms of chemical composition, but also in terms of outcomes such as structure, porosity, hardness and mechanical stability of the materials. The main objective of the surface change is to improve the performance of lignocellulosic biomass in the production of a suitable composite through chemical modification, such as alkaline treatment, which is enabled by the high density of $\mathrm{OH}$ groups on a typical lignocellulosic surface. The ecological consequences of this treatment must be carefully evaluated in relation to the approach using sustainable method and material and involves less energy and economical processing steps. Also, the nature and content of the main constituents of lignocellulosic biomass (lignin, hemicellulose and extractive substances naturally present in plant materials) can be expected to play a significant role in the development of the strategy for modifying the characteristics of cellulose with minimal harmful effects on the environment.

\section{EXPERIMENTAL}

\subsection{Reagents and materials}

All reagents used in this study were of analytical grade (Sigma-Aldrich Chemie $\mathrm{GmbH}$ ). The solutions for modification process, as well as to rinse obtained products, were prepared with deionized water $(18 \mathrm{M} \Omega)$. As the starting lignocellulosic material in this experiment was used the matured fruit of $L$. vulgaris from southern area of Serbia (near Leskovac), grown at an altitude of $250 \mathrm{~m}$. The naturally dried shell of $L$. vulgaris was 
manually emptied and crushed into 1 to $2 \mathrm{~cm}$ pieces. The raw material was soaked and washed with deionized water to remove dust and soluble impurities. The washed material was dried in an oven for $24 \mathrm{~h}$ at $60{ }^{\circ} \mathrm{C}$, milled in a crusher mill (Waring 8010 ES, Germany) and sieved to separate a size between 400 and $800 \mu \mathrm{m}$.

\subsection{Green carbonate treatment of biomass}

In order to prepare an effective biosorbent synthesis precursor (MBGS), a partially modified literary procedure [10] adjusted to the BGS biomass chemical composition was adapted for the treatment. In this regard, dried and crushed shell of L. vulgaris $(5 \mathrm{~g})$ was treated with $100 \mathrm{~cm}^{3}$ of weak alkaline solution (mixture of $1 \% \mathrm{Na}_{2} \mathrm{CO}_{3}$ and $1 \%$ $\mathrm{NaCl})$ for 4 hours at a temperature of $25 \pm 1{ }^{\circ} \mathrm{C}$ and atmospheric pressure, with constant mixing on a magnetic stirrer (150 rpm). The suspension was filtered (by $0.45 \mu \mathrm{m}$ of microfiltration membrane, Agilent Technologies, Germany) and washed with deionized water until discoloration. The residue was then dried at $80 \pm 1{ }^{\circ} \mathrm{C}$ to a constant weight. The prepared MBGS biomass was subjected to physicochemical, spectroscopic and morphological characterization.

\subsection{Characterization methods}

The constituents and physical properties of raw BGS biomass and MBGS precursor were determined according to the standard AOAC procedures [11]. The infrared spectra of the all investigated samples were recorded using a BOMEM MB-100 (Hartmann \& Braun, Canada) Fourier transform infrared spectrometer (FTIR), in the range of $4000-400 \mathrm{~cm}^{-1}$, at resolution of $2 \mathrm{~cm}^{-1}$ and with 16 scans. The obtained FTIR spectra were analyzed using Win Bomem Easy software. The SEM microscope system (JEOL JSM-6610LV) was used to examine the surface morphology of the BGS biomasses before and after alkaline treatment.

\section{RESULTS AND DISCUSSION}

\subsection{Chemical composition of BGS biomass}

Raw lignocellulosic BGS biomass was firstly subjected to direct examination (moisture, volatile matter, ash), of biochemical (cellulose, hemicellulose, lignin and protein) content and physical properties (density and bulk density) in accordance with standard AOAC procedures. A general description of lignocellulosic BGS material, compared to some unmodified agricultural nusproducts, is given in Table 1. The most common BGS biomass component is lignin. High content of holocellulose $(57.80 \pm 0.63 \%)$ in raw material indicates a significant presence of $\mathrm{OH}$ groups, as active centers for reactions during the biosorbent synthesis. The protein content is extremely low $(<0.1 \%)$. Volatile matter has not been detected since BGS is naturally dried material, which is one of the advantages of its application. Also, this plant material is characterized by low ash content, which mainly consists of bio-accumulated metals during plant growth, such as $\mathrm{Zn}(11.5 \mathrm{ppm}), \mathrm{Cu}(5.5 \mathrm{ppm})$, $\mathrm{Mn}(1.1 \mathrm{ppm})$ and others [8]. The biomass is characterized by a moisture content of $3.80 \pm 0.14 \%$, and a bulk density of $103.03 \pm 0.87 \mathrm{~kg} \mathrm{~m}^{-3}$. These data are in accordance with the other plant material characteristics from the genus Lagenaria [12].

Table 1. Chemical properties of raw lignocellulosic BGS biomass in comparison with some agro-biomasses [1]

Tabela 1. Hemijska svojstva sirove lignocelulozne BGS biomase u poređenju sa nekim poljoprivrednim biomasama [1]

\begin{tabular}{|c|c|c|c|c|c|}
\hline \multirow{2}{*}{ Parameter } & \multicolumn{5}{|c|}{ Values (based on 100 g of dry matter) } \\
\cline { 2 - 6 } & $\begin{array}{c}\text { BGS } \\
\text { biomass }\end{array}$ & Walnut shell & $\begin{array}{c}\text { Peanut } \\
\text { shell }\end{array}$ & $\begin{array}{c}\text { Almond } \\
\text { shell }\end{array}$ & $\begin{array}{c}\text { Rice } \\
\text { shell }\end{array}$ \\
\hline Cellulose (\%) & $39.58 \pm 0.42$ & 33.2 & 45.3 & 40.5 & 34.8 \\
\hline Hemicellulose (\%) & $18.22 \pm 0.14$ & 9.6 & 8.1 & 19.7 & 6.0 \\
\hline Lignin (\%) & $41.90 \pm 0.51$ & 48.3 & 32.8 & 27.2 & 17.2 \\
\hline Proteins (\%) & $<0.1$ & 1.4 & 4.9 & 1.9 & 3.2 \\
\hline Ash (\%) & $0.28 \pm 0.04$ & 3.5 & 2.3 & 2.9 & 21.9 \\
\hline Density $\left(\mathrm{g} \mathrm{cm}^{-3}\right.$ ) & $0.46 \pm 0.07$ & 0.64 & 0.43 & 0.22 & 0.27 \\
\hline
\end{tabular}

Comparative chemical composition analysis of the different agricultural nus-products (Table 1) shows that the BGS biomass is very similar by their nature to the scales, almonds, walnuts, and peanuts, taking into account the content of lignin and hemicellulose. However, it must be taken into account that the same plant material with different natural origin (habitat) may have a different composition, which will definitely affect its modification and future behavior [13].

\subsection{Effect of biomass alkaline treatment}

The purpose of this study is to determine the effect of the applied alkaline treatment on the 
chemical composition and structural changes of the lignocellulosic BGS biomass, in order to prepare the enriched cellulose precursors for further biosorbent synthesis. For ecological reasons, and because of the cellulose content preservation (an important structural biomass constituent), BGS biomass treatment was carried out using the green carbonate liquid under normal reaction conditions. The application of a weak alkaline $\mathrm{Na}_{2} \mathrm{CO}_{3}$ agent allows mild degradation of lignocellulosic biomass with increased delignification selectivity [14]. The results of the physicochemical analysis of the initial BGS biomass and MBGS precursor after alkaline treatment are shown in Table 2. All values that represent the mean values of three repeated measurements are expressed in percentages based on the weight of the dry matter.

Table 2. Physicochemical properties of the starting BGS biomass and MBGS precursor after alkaline treatment ( $1 \% \mathrm{Na}_{2} \mathrm{CO}_{3}$ and $1 \% \mathrm{NaCl}, 4 \mathrm{~h}, \mathrm{rpm} 150$, normal conditions)

Tabela 2. Fizičko-hemijska svojstva polazne BGS biomase i MBGS prekursora nakon alkalnog tretmana (1\% $\mathrm{Na}_{2} \mathrm{CO}_{3}$ i $1 \% \mathrm{NaCl}, 4 \mathrm{~h}, 150$ o/min, normalni uslovi)

\begin{tabular}{|c|c|c|c|c|}
\hline Parameter & BGS & Loss & MBGS before rinsing & MBGS after rinsing \\
\hline Mass & $5.00 \pm 0.01 \mathrm{~g}$ & $-15.2 \%$ & $4.24 \pm 0.01 \mathrm{~g}$ & $4.22 \pm 0.02 \mathrm{~g}$ \\
\hline Cellulose & $39.58 \pm 0.42 \%$ & $-0.0 \%$ & $47.01 \pm 0.33 \%$ & $47.12 \pm 0.26 \%$ \\
\hline Hemicellulose & $18.22 \pm 0.14 \%$ & $-71.4 \%$ & $6.14 \pm 0.08 \%$ & $6.01 \pm 0.13 \%$ \\
\hline Lignin & $41.90 \pm 0.51 \%$ & $-5.2 \%$ & $46.84 \pm 0.27 \%$ & $46.87 \pm 0.34 \%$ \\
\hline Solution color & colorless & brown-red & dark-yellow & colorless \\
\hline Solution pH & 6.7 (filtrate) & 10.1 (filtrate) & 8.6 (filtrate) & 6.8 (filtrate) \\
\hline
\end{tabular}

As shown by the results of physicochemical analysis before and after samples treatment (Table 2 ), the method efficiency is confirmed by the initial sample mass loss, as well as by color differences and filtrate $\mathrm{pH}$. The change in the BGS sample weight during alkaline treatment from $5.0 \mathrm{~g}$ to 4.24 g (15.2\%) indicated a change in the chemical composition of the lignocellulosic biomass. Thus, the treated product significantly reduced the content of hemicellulose $(71.4 \%)$ and partially lignin (from 5.2\%), which directly affected the cellulose enrichment of biomass. After washing the alkaline treated sample with deionized water, the increase in cellulose content from the initial $39.6 \%$ to the final $47.12 \%$ was observed. These results are in agreement with literature data [15], where only the rice straw biomass auto-hydrolysis (without alkali) at $120{ }^{\circ} \mathrm{C}$ achieved removal of the lignin to total $7.1 \%$, or by pretreatment with a mild alkaline solution $\left(4 \% \mathrm{Na}_{2} \mathrm{CO}_{3}\right)$ at $120{ }^{\circ} \mathrm{C}$ where $11.9 \%$ of lignin was removed. In the case of drastic conditions achieved by $\mathrm{Na}_{2} \mathrm{CO}_{3}$ reagent treatment application (e.g., an raised temperatures up to 150 ${ }^{\circ} \mathrm{C}$ and the concentration of alkali up to $20 \%$ ) a greater proportion of removed polysaccharides (> $30 \%$ ) from the biomass can be obtained [14], which was not the purpose of this research.

In addition, it is characteristic that during BGS alkaline treatment, the color solution becomes more intense (from a colorless to brown-red color), and that during multiple treated biomass washings, the deionised water of the filtrate passes from a dark yellow to a colorless filtrate. The characteristic brown-red color of the reaction solution during alkaline biomass treatment is probably derived from released pigments and created degradation products from the plant cell wall (organic resin compounds, pectin, oxidized phenols and some organic acids) [16]. Chemical reaction in the aquatic environment that is most likely present until biomass treatment is pectin release (heterosaccharide) from the cell wall [17], and only the pectin where break-up of glucosidic bonds is present can be separated from the chain. Due to the pectin depolymerization (as a polygalacturonic acid polymer) and hemicellulose, components such as cinnamic, glucuronic and galacturonic acid are released. At the same time, the $\mathrm{Ca}$ (II) ions that maintain the pectin structure are probably removed which influences the solid state breaking of biomass itself [17].

An important index for treatments efficacy estimation is the change in the $\mathrm{pH}$ of the solution. The high $\mathrm{pH}$ value of the starting solution (from 10.1) during the treatment of BGS biomass leads to the ester bonds elimination between cellulose, lignin and hemicellulose, as well as secondary reactions of polysaccharides (generally free of hemicellulose, which is significantly more sensitive to hydrolysis). Also, substituted hemicelluloses groups can be hydrolyzed to the form of acetic or uronic acid, which resulting in the formation of more acidic substances [18]. These organic acids lead to a pH decrease from 10.1 to 8.6 during alkaline treatment. To remove undesired agents (non-renewable alkaline salts) and released oligosaccharide or monomer constituents, the biomass was filtered and subsequently washed with deionized water until the dark yellow filtrate with a pH of 6.8. Results of these physicochemical 
tests confirmed that alkaline treatment leads to the partial release of certain constituents from the lignocellulosic matrix and the removal of their hydrolyzed fragments from the system. However, after the applied treatment procedure, it was found that approximately $78 \%$ of the total polysaccharides are retained in the treated BGS biomass.

\subsection{Spectroscopic characterization}

Comparable FTIR spectra of BGS biomass and MBGS precursor after alkaline treatment are shown in Fig. 2. Since to the high degree of mutual correlation of characteristic functional groups and chemical bonds vibration, the identified changes in the absorption IR bands of lignocellulosic biomass during treatment are closely related to the nature of the analyzed material and applied conditions. Characteristic vibrations of chemical bonds and assignment of IR bands of the corresponding functional groups of BGS biomass are summarized in Table 3.

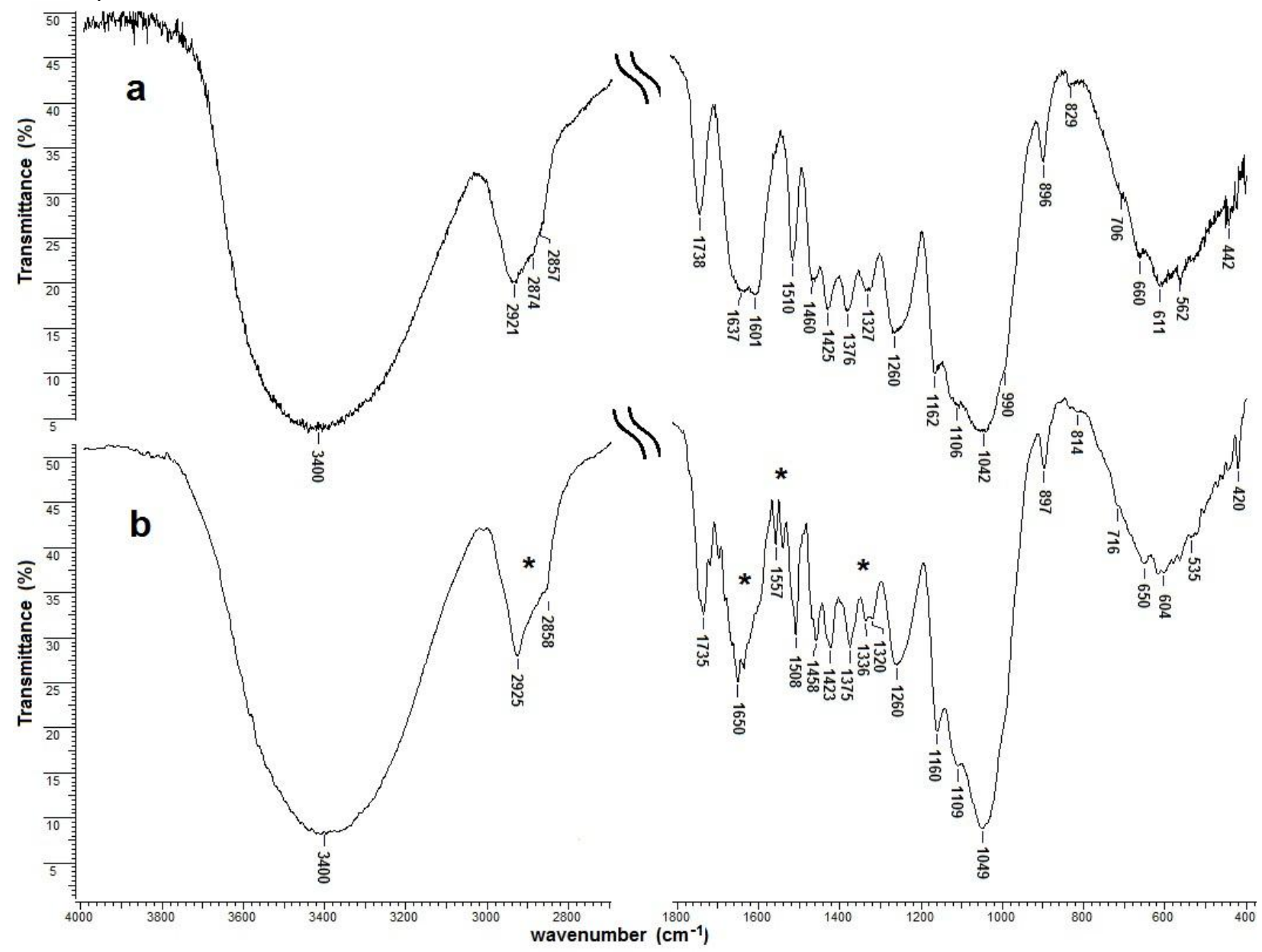

Figure 2. FTIR spectra of BGS biomass (a) and MBGS precursor (b) (characteristic changes in the spectral region are emphasized by asterisk)

Slika 2. FTIR spektri BGS biomase (a) i MBGS prekursora (b) (karakteristične promene u spektralnoj oblasti su naglašene zvezdicom)

The FTIR spectra of both analyzed samples (Fig. 2) in the region of $4000-2000 \mathrm{~cm}^{-1}$ are typical for the lignocellulosic biomass and hydrogen bonds presence. Due to the complex nature of biomass, no significant changes were observed in this region after alkaline treatment. $A$ wide band in the region of $3600-3000 \mathrm{~cm}^{-1}$ is valence vibrations characteristic of different types of $\mathrm{O}-\mathrm{H}$ groups present in biomass, as well as the expected complex electrostatic interactions (intra- and inter- hydrogen bonds) between constituents within the cell wall structure. The dominant bands at $2925 \mathrm{~cm}^{-}$ ${ }^{1}$ and $2858 \mathrm{~cm}^{-1}$ are characteristic for $\mathrm{C}-\mathrm{H}$ valence vibrations of aliphatic $-\mathrm{CH}_{2}$ and $-\mathrm{CH}$ groups of glucopyranose monomers, which are predominantly in correlation with the presence of holocellulose in the sample. The characteristic band of $\mathrm{C}-\mathrm{H}$ valence vibration at $2874 \mathrm{~cm}^{-1}$ in the BGS- IR spectrum (Fig. 2a) is in correlation with the present lignin, so it can be preliminarily used for behavior 
D. Z. Marković Nikolić et al. The green modification of lagenaria vulgaris agro-waste: spectroscopic ...

analysis during alkaline treatment. The intensity decrease of MBGS precursor band (Fig. 2b), which is not clearly apparent due to overlapping, indicates possible degradation and partial loss of lignin from the sample during alkaline treatment. The band at $1738 \mathrm{~cm}^{-1}$ is derived from saturated ester $\mathrm{C}=\mathrm{O}$ and is correlated with the presence of hemicellulose in the sample. The band intensity reduction in MBGS sample indicates that hydrolysis of glycosidic C-O$\mathrm{C}$ bonds, depolymerization of released hemicellulose and its partial removal from biomass results in hydrolysis during alkaline treatment. In the spectral BGS sample region 1700-1560 $\mathrm{cm}^{-1}$ there is a complex IR band (Fig. 2a), with centroids at about $1640 \mathrm{~cm}^{-1}$ and $1600 \mathrm{~cm}^{-1}$. This wide band indicates the overlap of $\mathrm{O}-\mathrm{H}$ vibrations of the water molecule (cellulose crystallohydrate), as well as the presence of phenolic and carboxyl groups with skeletal vibrations of lignin rings. The appearance of the band in this region is different after alkaline treatment (Fig. 2b). The more pronounced centroid is shifted to $1650 \mathrm{~cm}^{-1}$, while the intensity of the band is considerably reduced to about $1600 \mathrm{~cm}^{-1}$, which is characteristic of lignin-conjugated rings. The band at $1510 \mathrm{~cm}^{-1}$ is derived from skeletal vibration of the lignin aromatic ring and it is approximately the same intensity in both analyzed biomass samples.

Table 3. Assignation of absorption IR bands of lignocellulosic biomass [19] (characteristic changes are emphasized by asterisk)

Tabela 3. Asignacija apsorpcionih IR traka lignocelulozne biomase [19] (karakteristične promene su naglašene zvezdicom

\begin{tabular}{|c|c|c|c|c|c|}
\hline \multirow{2}{*}{ Band position $\left(\mathrm{cm}^{-1}\right)$} & \multirow{2}{*}{ Functional group } & \multirow{2}{*}{ Vibration } & \multicolumn{3}{|c|}{ Assignation } \\
\hline & & & Cellulose & Hemicellulose & Lignin \\
\hline 3400 & $\mathrm{O}-\mathrm{H}$ & valence & $\bullet$ & $\Delta$ & ! \\
\hline 2925 & $\mathrm{C}-\mathrm{H}$ & valence & $\bullet$ & $\Delta$ & - \\
\hline $2874^{*}$ & $\mathrm{C}-\mathrm{H}$ & valence & & & - \\
\hline 2858 & $\mathrm{C}-\mathrm{H}$ & valence & $\bullet$ & $\Delta$ & - \\
\hline $1738^{*}$ & $\mathrm{C}=\mathrm{O}$ & valence & & $\Delta$ & \\
\hline $1650^{*}$ & $\mathrm{C}=\mathrm{O}+\mathrm{C}=\mathrm{C}$ & valence & & & - \\
\hline 1637 & $\mathrm{H}-\mathrm{O}-\mathrm{H}$ & deformation & - & & \\
\hline $1600^{*}$ & $\mathrm{C}=\mathrm{C}$ aromatic & valence & & & - \\
\hline 1557 & $\mathrm{C}=\mathrm{C}$ aromatic & skeletal & & & - \\
\hline 1510 & $\mathrm{C}=\mathrm{C}$ aromatic & skeletal & & & - \\
\hline 1460 & $\mathrm{C}-\mathrm{H}$ & deformation & - & $\Delta$ & - \\
\hline 1425 & $\mathrm{O}-\mathrm{H}$ & deformation & - & $\Delta$ & - \\
\hline 1380 & C-H aliphatic & deformation & $\bullet$ & $\Delta$ & - \\
\hline 1335 & $\mathrm{C}-\mathrm{H}+\mathrm{O}-\mathrm{H}$ & deformation & - & $\Delta$ & - \\
\hline $1327^{\star}$ & ring $+\mathrm{C}-\mathrm{O}$ & deformation & & & syringyl \\
\hline 1310 & $\mathrm{CH}_{2}$ & deformation & - & $\Delta$ & \\
\hline 1280 & $\mathrm{C}-\mathrm{H}$ & deformation & crystalline & & \\
\hline 1270 & ring $+\mathrm{C}-\mathrm{O}$ & deformation & & & guaiacyl \\
\hline 1215 & $\mathrm{C}-\mathrm{C}+\mathrm{C}-\mathrm{OH}$ & valence & & & - \\
\hline 1200 & $\mathrm{O}-\mathrm{H}$ & deformation & - & $\Delta$ & \\
\hline 1160 & C-O-C & asym. val. & $\bullet$ & $\Delta$ & \\
\hline 1109 & $\mathrm{C}-\mathrm{OH}$ & valence sec. & $\bullet$ & $\Delta$ & \\
\hline 1086 & $\mathrm{C}-\mathrm{OH}$ & deform. sec. & $\bullet$ & $\Delta$ & - \\
\hline 1049 & $\mathrm{C}-\mathrm{O}+\mathrm{C}-\mathrm{C}-\mathrm{O}$ & valence & $\bullet$ & $\Delta$ & - \\
\hline 990 & $\mathrm{C}-\mathrm{O}$ & valence & $\bullet$ & & \\
\hline 960 & $\mathrm{H}-\mathrm{C}=\mathrm{C}-\mathrm{H}$ & deformation & & & - \\
\hline 897 & $\mathrm{C}-\mathrm{H}$ & $\beta$-glycosidic & $\bullet$ & $\Delta$ & \\
\hline 830 & $\mathrm{C}-\mathrm{H}+\mathrm{C}=\mathrm{C}$ & deformation & & $\Delta$ & I \\
\hline$<830$ & $\mathrm{C}-\mathrm{H}+\mathrm{O}-\mathrm{H}$ & deformation & $\bullet$ & $\Delta$ & - \\
\hline
\end{tabular}

However, MBGS sample was characterized by the appearance of doublet at about $1557 \mathrm{~cm}^{-1}$ which indicating different types of aromatic $\mathrm{C}=\mathrm{C}$ skeletal vibrations of lignin fragments. This is supported by the possibility of the presence of lignin fragments of a different nature in the 
analyzed samples [19]. Namely, lignin subunits that are incorporated into the polymer can be identified by the characteristic structure of the aromatic rings, from which are the most important guaiacyl (the most common in softwood), syringyl (in hardwood) and p-hydroxyphenyl (in smaller quantities in grass) (Fig. 3). Molecules consist of methoxyl, acetyl and formyl groups. This difference in composition has a major impact on<smiles>Cc1ccc(OC(C)(C)C)c(C(C)(C)C(=O)OCC(C)(C)C)c1</smiles>

p-Hydroxyphenyl delignification, as well as on biomass destruction. Typically, guaiacyl units are more often networked at the C-5 position of the aromatic ring, so these cross-linked $\mathrm{C}-\mathrm{C}$ bonds (formed during lignification) make it difficult to delignify biomass since they cannot be hydrolyzed either by acid or base [20]. Contrary to that, the C-5 position in syringyl units is substituted, and therefore cannot participate in the reactions of further substitution.

Figure 3. Monolinols and their subunits; monomers vary by substitution to $C-3$ and $C-5$ position of the ring

\section{Slika 3. Monolinoli i njihove podjedinice; monomeri variraju supstitucijom na C-3 i C-5 poziciji prstena}

Thus, the intense band at about $1650 \mathrm{~cm}^{-1}$ in the FTIR spectrum of treated sample (Fig. 2b) corresponds to $\mathrm{C}=\mathrm{C}$ valence vibrations in the monomeric side chain within the lignin polymer, while the low intensity band at $1327 \mathrm{~cm}^{-1}$ corresponds to the vibration of the condensed syringyl G-ring, i.e. coniferyl alcohol substituted at C-5 position (Fig. 3). Spectral analysis confirms an $\mathrm{C}=\mathrm{C}$ side chains group increase (the band moving to $1650 \mathrm{~cm}^{-1}$ with intensity increasing), while reducing the amount of condensed structures (decreasing the intensity of the band to about 1600 $\mathrm{cm}^{-1}$ and doubling the band to about $1327 \mathrm{~cm}^{-1}$ ), which are characteristic of polymers formed by mixing coniferyl alcohol with ferulic acid (hydroxycinnamic acid). The IR band doubling (from $1327 \mathrm{~cm}^{-1}$ to 1336 and $1320 \mathrm{~cm}^{-1}$ ), that is less pronounced in the untreated BGS sample, indicate lignin polymer of pure coniferyl alcohol presence in the MBGS sample (after treatment). A small intensity increase of band at $1260 \mathrm{~cm}^{-1}$ in the FTIR spectrum can be explained by an increase in the number of $\mathrm{C}-\mathrm{O}$ bonds due to the presence of ferulic acid in the lignin polymer. Different active bands relations in the MBGS sample, to about $1423 \mathrm{~cm}^{-1}, 1260 \mathrm{~cm}^{-1}, 1050 \mathrm{~cm}^{-1}$ and the transit at $956 \mathrm{~cm}^{-1}$, compared to the complex band at about $1630 \mathrm{~cm}^{-1}$ in BGS biomass, indicate that lignin polymers differ by ferulic acid content and have clear structural differences. This fact also confirms the effect of alkaline treatment on the structural changes of the lignin biomass constituent.
In addition, in the spectrum of MBGS sample (Fig. 2b) the doubling of the band at $1460 \mathrm{~cm}^{-1}$ was detected, which originates from $\mathrm{C}-\mathrm{H}$ deformation vibrations (in the plane) of all the present biomass constituents. This fact points to the effect of alkaline treatment in the term of inter and intramolecular matrix hydrogen bonds break (Fig. 4), and thus, a better separation of biomass constituents and their clearer insight into the spectrum. FTIR bands at $1375 \mathrm{~cm}^{-1}$ (C-H vibrations) and $1327 \mathrm{~cm}^{-1}$ (C-O vibrations) may be correlated with the xyloglucan presence in the cell wall (the major hemicellulose polysaccharide, an enzyme that catalyzes $\beta$-1,4-bonds). However, it should be noted that these bands, together with a of deformation vibration band of $\mathrm{OH}$ group (in plane) at $1423 \mathrm{~cm}^{-1}$ and a wide band of the vibration of the cellulose ester group at $1260 \mathrm{~cm}^{-1}$, are correlated with the crystalline cellulose structure [21]. Thus, the apparently small changes in the bands intensity indicate a proportional change in the fraction of the crystalline to amorphous form of certain cellulose areas in the treated sample, which favors more efficient biosorbent synthesis based on this precursor.

A wide band in the $1100-900 \mathrm{~cm}^{-1}$ range, which is characteristic of most polysaccharides, shows a significant overlap of $\mathrm{C}-\mathrm{OH}$ and $\mathrm{C}-\mathrm{C}-\mathrm{O}$ vibrations at BGS sample (with a inflection at $990 \mathrm{~cm}^{-1}$ ). Its finer structure observed in the MBGS spectrum, where the maximum of the intensive band is moved from $1040 \mathrm{~cm}^{-1}$ to $1050 \mathrm{~cm}^{-1}$. A band at $830 \mathrm{~cm}^{-1}$ in the 
FTIR spectrum of BGS (Fig. 2a) is characteristic of anomeric $\alpha$-glucosidic bonds of hemicellulose that occurs only in the cell wall of the BGS biomass. In MBGS sample, the intensity of this band is greatly reduced due to hemicellulose destruction, which resulting in the appearance of the band at $815 \mathrm{~cm}^{-1}$, that derives from deformation $\mathrm{C}=\mathrm{C}$ vibrations of

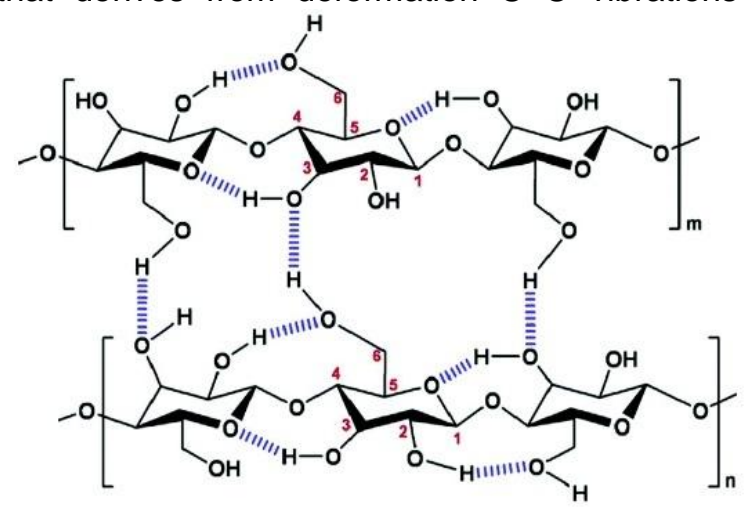

lignin fragments. The deformation $\mathrm{C}-\mathrm{H}$ vibrations characteristic of the anomeric $\beta$-glycosidic (C-O$\mathrm{CH})$ bonds of cellulose at $896 \mathrm{~cm}^{-1}$ and $990 \mathrm{~cm}^{-1}$ remain unchanged during treatment which suggest the structural stability of the cellulose chain to adequately applied reaction conditions.

\section{Figure 4. Structure of the cellulose fragment with characteristic inter and intra-hydrogen bonds in the plane and between the lamellas}

\section{Slika 4. Struktura celuloznog fragmenta sa karakterističnim inter i intra-vodoničnim vezama u ravni i između lamela}

Based on the FTIR spectral analysis of the tested samples, it can be concluded that during alkaline treatment of lignocellulosic BGS biomass (using a sodium-carbonate solution, under mild conditions) occur: a) destruction of the lignin matrix structure (hydrolysis of ester bonds of molecules such as ferulic and acetic acid); b) disturbance of the interaction between lignocellulosic components (breaking of inter- and intra-hydrogen bonds); c) release of hemicellulose molecules due to hydrolysis of ester bonds between hemicelluloses xylan and cellulose; d) degradation and dissolution of more susceptible hemicelluloses, due to the low degree of polymerization, branched structure and amorphous nature (removal of hemicelluloses xylan is significantly higher than glucan crystalline cellulose); e) subsequent dissolution and removal of ash and mineral matter, as well as the resulting by-products (phenolic and acid type) that would have a negative effect on the subsequent modification of biomass to the target biosorbent. These conclusions are in accordance with the other authors discussion about the alkaline treatment conducted on lignocellulosic biomasses of similar constitution $[22,23]$.

In general, these studies have shown the significance and importance of treatment lignocellulosic BGS biomass applying. It was noted that the alkaline biomass treatment, which involves the $\mathrm{Na}_{2} \mathrm{CO}_{3}$ alkali use, conducted in normal conditions, leads to a higher stable polysaccharides yield production useful for more efficient cationic biosorbent synthesis. The advantage of carbonate as the chemical agent for the biomass treatment in relation to more aggressive alkali $(\mathrm{NaOH}$ or $\mathrm{KOH})$, is primarily due to ecological character. In addition, it is also reflected through the effective delignification of biomass (with the protection of the structure of essential polysaccharides), as well as their conversion to amorphous form (swelling and de-crystallization of cellulose). The presence of $\mathrm{NaCl}$ in the solution contributes to the dissolution and isolation of released inorganic plant matter (ash and minerals) from the cell wall. For their removal from the system, multiple washings with deionized water must be used, since they can be deeper incorporated into the biomass. In addition to the above facts, one of the most significant results of such treatment is the desired biomass morphology, which was confirmed by the results of the morphological characterization of the samples, which will be discussed trough the further studies.

Changes in hemicellulose and lignin content have a significant impact on the final biomass structure. Thus, in addition to reducing the stiffness of cellulosic fibers, treatment also leads to the creation of new capillary spaces between elemental plant fibers, as well as an increase in the degree of porosity of the entire cell wall [24]. After the treatment, in the final biomass are present cellulose, residual lignin and part of still trapped hemicelluloses that is left behind in the internal compact structure of biomass, which can be presented with the appropriate model (Fig. 5). The 
higher specific surface biomass areas, lower interfibrillar areas density in the structure, as well as lignocellulosic fibers amorphousness, are important preconditions for a good precursor for the synthesis of cationic biosorbent with greater sorption capacity.

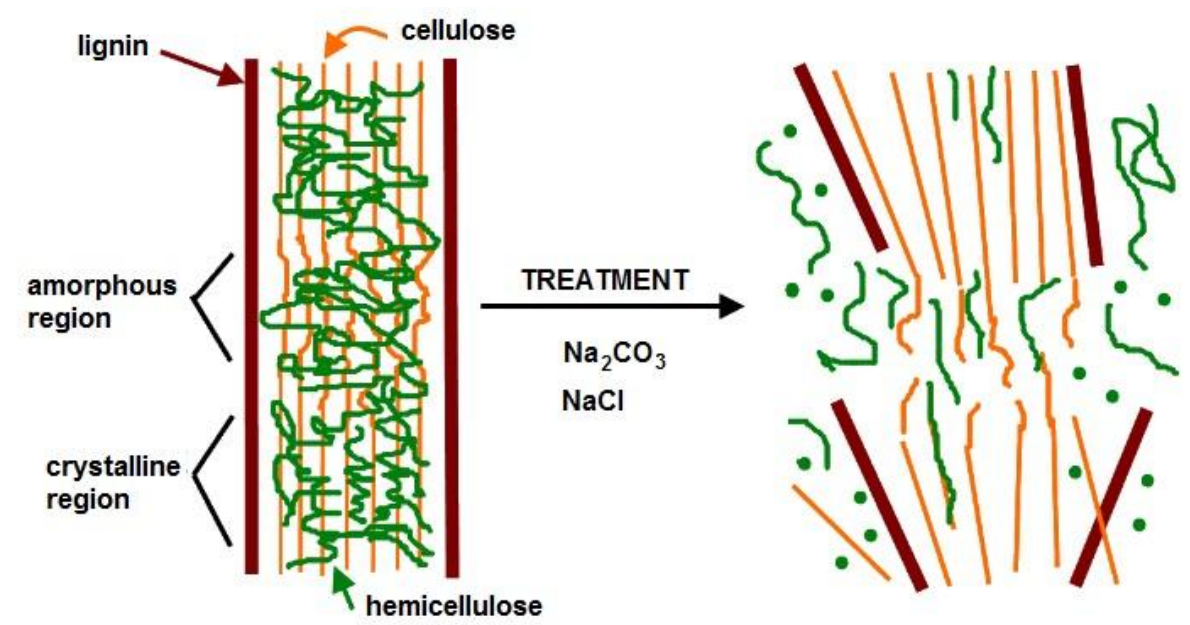

Figure 5. Schematic presentation of lignocellulosic biomass treatment effect (adapted [16])

Slika 5. Šematski prikaz efekta tretmana lignocelulozne biomase (prilagođeno iz [16])

\subsection{Morphological analysis}

The morphology of solid phase surfaces is a very important characteristic of biomasses [8]. For the morphological analysis of BGS biomass surface during alkaline modification the scanning electron microscopy (SEM) method was applied. The corresponding SEM micrographs of the raw BGS biomass are shown in Fig. 6. The morphological analysis of biomass indicates the presence of large particles (about 500-600 $\mu \mathrm{m}$ ), with irregular shape and porous structure, with pores of different

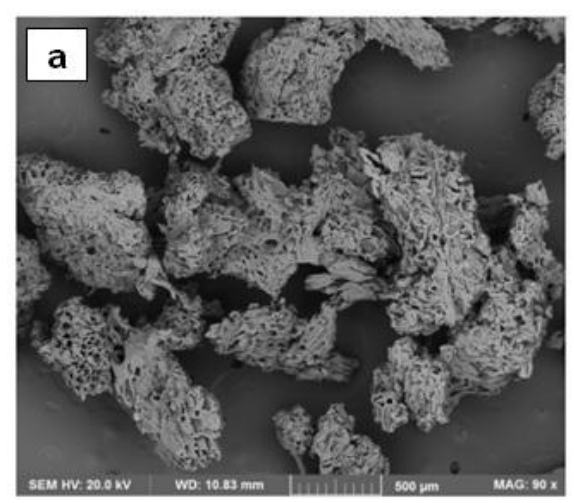

shapes and sizes (Fig. 6a). On a micro level, BGS biomass is mainly composed of small, unorganized plant cells of various sizes $(20-40 \mu \mathrm{m})$ and different morphologies. In addition, macro-pores of nonuniform size $(0.5-1.5 \mu \mathrm{m})$ can be noticed; these pores contribute to the relatively larger specific surface of the biomass (Fig. 6b). Similar pore morphology has already been reported in other lignocellulosic materials and their activated carbons [25].

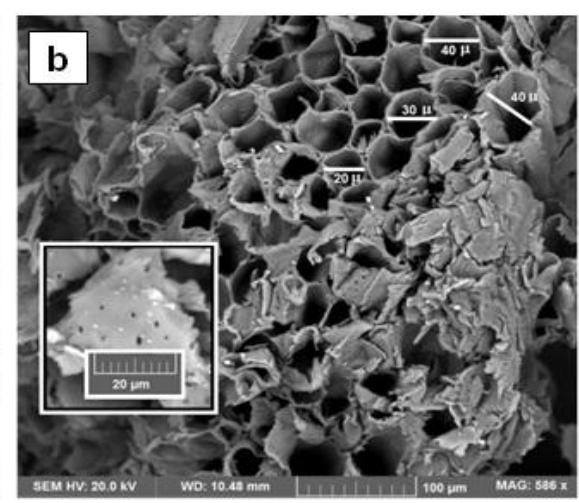

Figure 6. SEM micrographs of the raw BGS biomass at various magnitudes

\section{Slika 6. SEM mikrografi sirove BGS biomase pri različitim uvećanjima}

Regarding the morphological characteristics, the lignocellulosic structure of BGS biomass is in accordance with the theoretical model of the structural block of woody fibrous cells (Fig. 7). The size of the fibrous cells varies from 16 to $42 \mu \mathrm{m}$ in diameter, or from 870 to $4000 \mu \mathrm{m}$ in length, so that
$1 \mathrm{~cm}^{3}$ of biomass contains more than 1.5 million cells [26]. Each single cell has a multilayered structure of the closed tube (Fig. 7a), unlike to the homogeneous wall of the non-ligneous cellulosic straw. Each individual cell is characterized by four layers of the cell wall (primary, S1, S2, and S3), 
whereby each layer is made from three chemical polymers: cellulose and hemicellulose (linear polysaccharides) and lignin (amorphous phenol as an adhesive for cellulose microfibrils). Well- packaged cells lead to the formation of a strong composite seen in confocal micrographs, where the fiber represents a set of spiral micro-fibrils (Fig. $7 b)$.
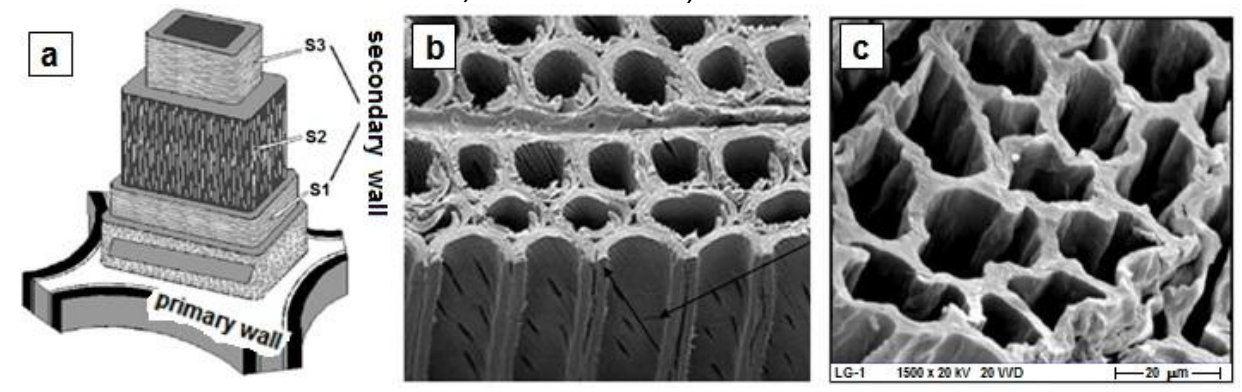

Figure 7. Model of the layered structure of mature (a) fibrous plant cells [26] and corresponding SEM micrographs of lignocellulosic microfibrils before (b) and after (c) biomass treatment [27]

Slika 7. Model slojevite strukture zrelih (a) vlaknastih biljnih ćelija [26] i odgovarajući SEM mikrografi lignoceluloznih mikrofibrila pre (b) i posle (c) tretmana biomase [27]

In addition, the polysaccharides and the phenolic component fit into a layered tubular shape with a large cellular cavity, which significantly affects the variation in the specific weight of the material. This layered tubular structure provides a large volume of voids [27], especially after chemical treatment of biomass (Fig. 7c). As earlier noted, the alkaline treatment of BGS biomass can change the macroscopic and microscopic properties of the lignocellulosic material, including particle size, structure and chemical composition of biomass, which is of great importance for the target synthesis process. It is already known, based on the physicochemical characterization, that biomass treatment with carbonate solutions leads to several effects, such as: swelling of the internal surface of biomass, breakdown of lignin, disturbance of links between lignin and other constituents, decrease in the degree of hemicellulose polymerization, and reduction of cellulose crystallinity [28]. Various SEM micrographs of the BGS biomass sample during alkaline treatment (Fig. 8) show that the specific surface of biomass could be increased with applied treatment, due to partial delignification and consequent depolymerization of chemically sensitive hemicellulose. The disintegration of biomass particles during alkaline treatment has reflected on the appearance of a significantly disturbed surface of the outer walls and the flattened ends of cellulose microfibrils. This could provide better accessibility of the modifying agent within the cell wall leading to the effective conversion of cellulose, which is now more available, to the desired product. The treatment also involves the separation of cellulosic biomass from other components, such as lignin, hemicellulose and pectin, which could significantly increase the yield of modified product [29].
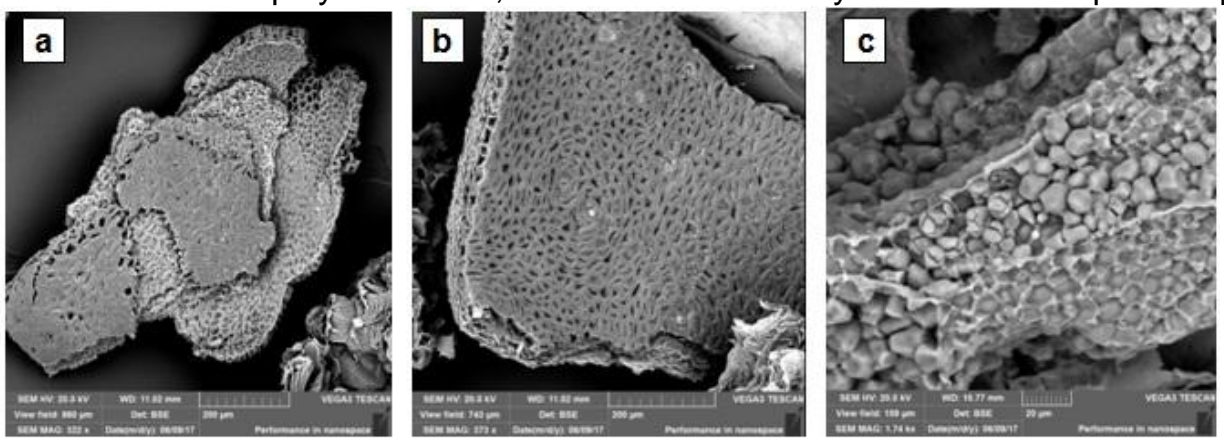

Figure 8. Characteristic morphological changes in BGS biomass during alkaline treatment

\section{Slika 8. Karakteristične morfološke promene u BGS biomasi tokom alkalnog tretmana}

The morphological characteristics of the MBGS precursor, obtained by the alkaline biomass treatment, are shown in Fig. 9. It is evident that the treatment process affects the increase in specific surface of the starting biomass. Namely, the previous analysis of the surface area and porosity of the raw BGS biomass using the isotherm of the nitrogen sorption/desorption process have shown 
that nitrogen saturation is achieved at a relatively low gas pressure values [30]. The small value of the adsorbed gas volume in equilibrium $\left(0.28 \mathrm{~cm}^{3}\right.$ $\mathrm{g}^{-1}$ ) was indicated a small specific surface area of the raw biomass, without pronounced porosity. Using the BET (Brunauer-Emmett-Teller) method [30], a total specific area of $1.08 \mathrm{~m}^{2} \mathrm{~g}^{-1}$ was determined, with the outer surface of the raw BGS biomass $\left(0.23 \mathrm{~m}^{2} \mathrm{~g}^{-1}\right)$ having a relatively small share in the total area. The biomass area is predominantly characterized by mesopores (with diameters between 20 and $50 \mathrm{~nm}$ ), while the remaining specific surface is represented by macropores and surface elements (cavities and channels) of significantly larger dimensions than standard pores. On the contrary, the SEM micrographs of MBGS precursor (Fig. 9) show a highly porous morphology with pores of irregular shapes and non-uniform sizes. This alkaline treated biomaterial exhibits somewhat changed morphology with extended surface arrangement regarding the repetition of structures, plant vessel orientations, the subsistence of pores of comparable shapes and sizes, and the smallest openings becoming more available for reactants.
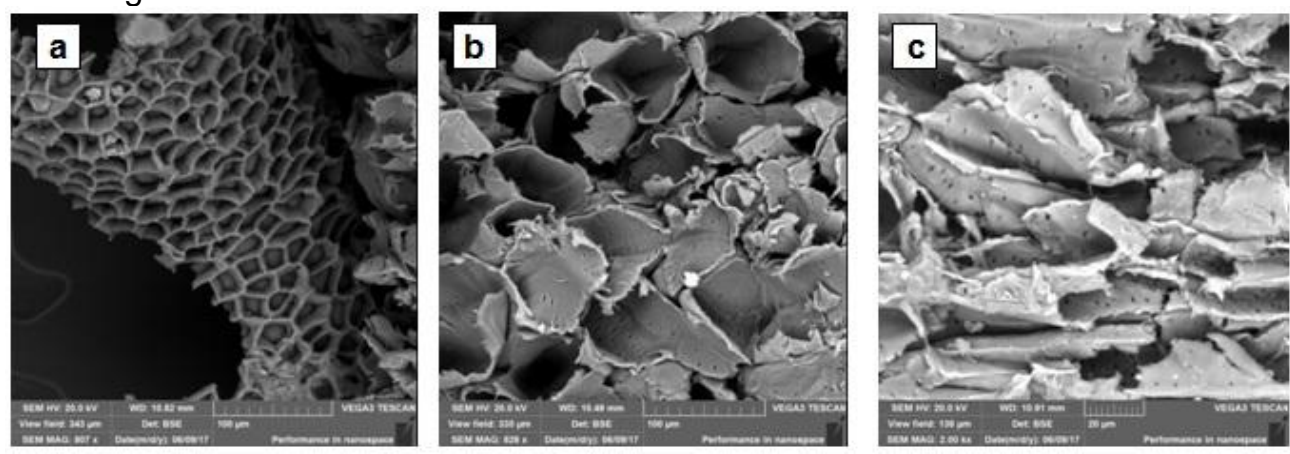

Figure 9. SEM micrographs of MBGS precursor at various magnitudes

\section{Slika 9. SEM mikrografi MBGS prekursora pri različitim uvećanjima}

\section{CONCLUSION}

The study presents a green carbonate process of bottle gourd shell modification and clarifies the effect of the applied treatment on the chemical composition and structural changes of the lignocellulosic biomass. The application of a weak alkaline solution $\left(1 \% \mathrm{Na}_{2} \mathrm{CO}_{3}\right.$ and $\left.1 \% \mathrm{NaCl}\right)$ under normal reaction conditions (room temperature and atmospheric pressure) allows mild destruction of the lignocellulosic biomass with increased delignification selectivity. The green process efficiency is confirmed by the initial sample mass loss $(15.2 \%)$, as well as by color differences and $\mathrm{pH}$ of filtrate (from 10.1 to 6.8 ), indicating a change in the chemical composition of the lignocellulosic biomass. Based on the FTIR spectroscopic analysis, significant chemical and structural
The existence of plant vessels with horizontal and vertical orientation as well as different cavities on the external surface can be seen, which may contribute to the relatively larger surface area of MBGS precursors compared to BGS biomass. The analysis of MBGS precursor by BET method gave an assessment the total specific area of $2.24 \mathrm{~m}^{2} \mathrm{~g}$ 1 , which is a higher result than the specific surface of raw BGS biomass by approximately 2 times [31]. In addition, during the alkaline treatment, the biomaterial retains the solid nature of the structure, made of cellulose and lignin, which is characterized by mechanical resistance and compactness as important characteristics for applying the MBGS biomass as a sorbent. The presence of macropores and large cavities can allow better mobility of the aqueous phase through the structure of the material and promote the internal diffusion. In this way, the prerequisite for successful synthesis of biosorbent is achieved, since the number of available reaction sites (primarily $-\mathrm{OH}$ groups on cellulosic microfibrils) for further modification of biomass by adequate reagent is increased. changes that occur in biomass during alkaline treatment have been identified. It was found that the applied alkaline treatment of lignocellulosic biomass leads to several effects: destruction of the lignin matrix structure, disturbance of the interaction between lignocellulosic components, depolymerization of more susceptible hemicelluloses, partial reduction of cellulose crystallinity, removal of mineral matter and resulting by-products (phenolic and acid type). The morphological SEM analysis showed that the porosity and specific surface of biomass could be significantly increased with applied treatment. This modified material supposed to have a high potential as precursor for biosorbent synthesis and other value added products in industrial applications. 


\section{Acknowledgement}

This study was supported by the Serbian Ministry of Education, Science, and Technological Development through the Project TR 34012. The authors are thankful to $\operatorname{Dr}$ Ljubiša Balanović (Technical faculty, Bor) for expert assistance in morphological analysis.

\section{REFERENCES}

[1] L.H.Wartelle, W.E.Marshall (2006) Quaternized agricultural by-products as anion exchange resins, Journal of Environmental Management, 78, 157162.

[2] M.A.Hubbe, O.J.Rojas, L.A.Lucia (2015) Green modification of surface characteristics of cellulosic materials at the molecular or nano scale: a review, Bio Resources, 10(3), 6095-6206.

[3] V.Chaturvedi, P.Verma (2013) An overview of key pretreatment processes employed for bioconversion of lignocellulosic biomass into biofuels and value added products, Biotechnology, 3(5), 415-431.

[4] D.Dai, M.Fan (2013) Green modification of natural fibres with nanocellulose, RSC Advances, 3, 46594665.

[5] NRCS (2019) Lagenaria siceraria, Natural Resources Conservation Service Plants Database, USDA, https://plants.usda.gov, retrieved: 10 March 2019.

[6] R.P.Prajapati, M.Kalariya, S.K.Parmar, N.R.Sheth (2010) Phytochemical and pharmacological review of Lagenaria sicereria, Journal of Ayurveda and Integrative Medicine, 1(4), 266-272.

[7] A.S.Rahman (2003) Bottle gourd (Lagenaria siceraria): A vegetable for good health, Natural Product Radiance, 2, 249-250.

[8] D.L. Mitic-Stojanovic, A.Zarubica, M.Purenovic, D. Bojic, T. Andjelkovic, A. Bojic (2011) Biosorptive removal of $\mathrm{Pb}^{2+}, \mathrm{Cd}^{2+}$ and $\mathrm{Zn}^{2+}$ ions from water by Lagenaria vulgaris shell, Water SA, 37(3), 303-312.

[9] M.B.C.Ocreto (2013) Delignification of lignocellulosic biomass for bioethanol production Review, USM Research and Development Journal, 21(1), 1-20.

[10] J.A.Laszlo (1996) Preparing an ion exchange resin from sugarcane bagasse to remove reactive dye from wastewater, Textile Chemists and Colorists, 28, 13-17.

[11] Association of Official Analytical Chemists (2016) Official Methods of Analysis, 20th ed., AOAC International.

[12] A.Singh, R.K.Sharma, M.Agrawal, F.M.Marshall (2010) Risk assessment of heavy metal toxicity through contaminated vegetables from waste water irrigated area of Varanasi, Tropical Ecology (India), 51(2S), 375-387.

[13] S.Hena, S.Atikah, H.Ahmad (2015) Removal of phosphate ion from water using chemically modified biomass of sugarcane bagasse, International Journal of Engineering Science, 4(1), 51-62.
[14] K.Kaur, U.G.Phutela (2016) Sodium carbonate pretreatment: an approach towards desilication of paddy straw and enhancement in biogas production, Paddy and Water Environment, 14, 113121.

[15] M.Taniguchi, H.Suzuki, D.Watanabe, K.Sakai, K. Hoshino, T. Tanaka (2005) Evaluation of pretreatment with Pleurotus ostreatus for enzymatic hydrolysis of rice straw, Journal of Bioscience and Bioengineering, 100, 637-643.

[16] N.Mosier, R.Hendrickson, N.Ho, M.Sedlak, M.R. Ladisch (2005) Optimization of pH controlled liquid hot water pretreatment of corn stover, Bioresource Technology, 96(18), 1986-1993.

[17] D.J.Cosgrowe (2005) Growth of the plant cell wall, Nature Reviews, 6, 850-861.

[18] V.S.Chang, M.T.Holtzapple (2000) Fundamental factors affecting biomass enzymatic reactivity, Applied Biochemistry and Biotechnology A, 84-86, 5-37.

[19] F.Xu, J.Yu, T.Tesso, F.Dowell, D.Wang (2013) Qualitative and quantitative analysis of lignocellulosic biomass using infrared techniques: a mini-review, Applied Energy, 104, 801-809.

[20] A.Brandt, J.Gräsvik, J.Hallett, T.Welton (2013) Deconstruction of lignocellulosic biomass with ionic liquids, Green Chemistry, 15, 550-583.

[21] R.M.Silverstein, G.C.Bressler, T.C.Morril, Spectrometric identification of organic compounds, 5th ed., John Wiley \& Sons, New Jersey, 2005.

[22] L.Yang, J.Cao, Y.Jin, H.Chang, H.Jameel, R. Phillips, Z.Li (2012) Effects of sodium carbonate pretreatment on the chemical compositions and enzymatic saccharification of rice straw, Bioresource Technology, 124, 283-291.

[23] R.C.Sun, J.Tomkinson, P.L.Ma, S.F.Liang (2000) Comparative study of hemicellulose from rice straw by alkali and hydrogen peroxide treatments, Carbohydrate Polymers, 42, 111-122.

[24] D.Loqué, H.V.Scheller, M.Pauly (2015) Engineering of plant cell walls for enhanced biofuel production, Current Opinion in Plant Biology, 25, 151-161.

[25] D.Bojić, M.Momčilović, D.Milenković, J.Mitrović, P. Banković, N.Velinov, G.S.Nikolić (2017) Characterisation of a low cost Lagenaria vulgaris based carbon for ranitidine removal from aqueous solutions, Arabian Journal of Chemistry, 10(7), 956964.

[26] T.Tabet, F.Aziz (2013) Cellulose microfibril angle in wood and its dynamic mechanical significance, Ch. 5, In: Cellulose - Fundamental Aspects, InTech, 113-142.

[27] M.Zviely (2013) Converting lignocellulosic biomass to low cost fermentable sugars. In: Pretreatment techniques for biofuels and biorefineries, Fang $\mathrm{Z}$. (Ed), Green Energy and Technology, Springer, Berlin, Heidelberg.

[28] S.Kim, M.T.Holtzapple (2005) Delignification kinetics of corn stover in lime pretreatment, Bioresource Technology, 97(5), 778-785. 
[29] D.Z.Marković Nikolić, A.Bojić, G.Petković, N.Ristić, M.Cakić, G.S.Nikolić (2017) The preparation and utilization of the cationic sorbent based on the surfactant modified bottle gourd shell, Advanced Technologies, 6(2), 38-50.

[30] D-L.Mitic-Stojanović (2012) Removal of heavy metals from water by biosorbent based on
Lagenaria vulgaris, Doctoral dissertation, Faculty of Sciences and Mathematics, University of Niš.

[31] D.Z.Marković (2018) Synthesis of cationic lignocellulosic sorbents and application for the removal of anionic pollutants from water, Doctoral dissertation, Faculty of Sciences and Mathematics, University of Niš.

\section{IZVOD}

\section{ZELENA MODIFIKACIJA LAGENARIA VULGARIS AGRO-OTPADA: SPEKTROSKOPSKA I MORFOLOŠKA ANALIZA}

$U$ poslednje vreme aktivno se provode istraživanja o iskorišćenju $i$ konverziji poljoprivrednih ostataka u proizvode sa dodatom vrednošću za dobijanje različitih važnih biomolekula od ekonomskog značaja. Stoga je u ovoj studiji analizirana modifikacija kore tikve sudovnjače (Lagenaria vulgaris), kao potencijalno vrednog poljoprivrednog otpada, zelenim karbonatnim tretmanom. Biohemijski sastav, strukturne $i$ morfološke promene biomase kore tikve tokom tretmana praćene su pomoću fizičko-hemijskih, spektroskopskih (FTIR) i mikroskopskih (SEM) metoda. Otkrivena je delimična delignifikacija i uklanjanje ekstraktivnih supstanci iz lignocelulozne biomase, kao što su oligosaharidi depolimerizovane hemiceluloze, organske kiseline, fragmenti lignina i eventualno zarobljeni minerali. Na ovaj način postignuta je povećana poroznost celulozom obogaćene biomase, kao i aktivacija celuloznih mikrofibrila u alkalnu celulozu. Utvrđeno je da su ove promene važan preduslov za izradu prekursora biosorbenta koji se može primeniti u tehnologiji tretmana otpadnih voda.

Ključne reči: tikva sudovnjača, lignocelulozna biomasa, modifikacija, zeleni rastvor, FTIR, SEM.

Naučni rad

Rad primljen: 27. 03. 2019.

Rad prihvaćen: 30. 04. 2019.

Rad je dostupan na sajtu: www.idk.org.rs/casopis

(C) 2019 Authors. Published by Engineering Society for Corrosion. This article is an open access article distributed under the terms and conditions of the Creative Commons Attribution 4.0 International license (https://creativecommons.org/licenses/by/4.0/) 